\title{
NOTES
}

\section{ANTITRUST: TRADE ASSOCIATION'S REFUSAL TO DEAL HELD A PER SE VIOLATION}

T HE conclusive presumption of illegality of group boycotts under the Sherman Act has recently been strengthened by Radiant Burners, Inc. v. Peoples Gas Light E' Coke Co., ${ }^{1}$ where the per se doctrine was applied to a trade association's refusal to deal.

A manufacturer of gas burners brought an action under Sections $4^{2}$ and $16^{3}$ of the Clayton Act alleging that the American Gas Association (AGA) and several of its members ${ }^{4}$ were conspiring to restrain trade in violation of Section $\mathrm{I}^{5}$ of the Sherman Act. AGA operated testing laboratories, affixing a "seal of approval" on all gas appliances meeting its standards. Claiming that those standards were not objective and that AGA's determinations were made capriciously, the plaintiff asserted that its burner, although safer and more efficient than ones previously approved by AGA, was refused approval. The plaintiff further alleged that AGA's purpose of controlling the market was ultimately effectuated by the member utility companies' refusing to provide gas for use in burners not approved by AGA, thus effectively excluding its burner from the market.

The district court dismissed on the ground that the complaint failed to state a claim upon which relief could be granted. The Court of Appeals affirmed, ${ }^{6}$ holding that no per se violation was established and that in the absence of a per se violation, "public injury" must be alleged. The court found that the plaintiff had failed to allege "public injury"

${ }_{3}^{1} 6_{4}$ U.S. 656 (r96x).

"Any person who shall be injured ... by reason of anything forbidden in the antitrust laws may sue therefore in any district court . . . and shall recover threefold the damages by him sustained ..." 38 Stat. 73 (1914), 15 U.S.C. $\$ 15$ (1958).

3 "Any person ... shall be entitled to sue for and have injunctive relief . . . against threatened loss or damage by a violation of the antitrust laws . . " 38 Stat. 737 (r9 14 ), $x_{5}$ U.S.C. $\$ 26$ ( 1958 ).

-The members of AGA joined as defendants were two public utility companies engaged in the distribution of gas, two pipeline companies engaged in the transportation of natural gas, and six manufacturers of gas burners.

"Every contract, combination . . . or conspiracy, in restraint of trade or commerce among the several States . . is declared to be illegal . . ." 26 Stat. 209 (r89o), $x_{5}$ U.S.C. \& $\times\left({ }^{9} 95^{8}\right)$.

${ }_{273}$ F.2d 196 (7th Cir. 1959). 
because the complaint did not show "any appreciable lessening" in the sale of conversion gas burners or gas furnaces or that the public had been deprived of a product of over-all superiority. The Supreme Court reversed, holding that refusal to sell consumers gas for use in burners not approved by AGA was a per se violation of the Sherman Act.

Although the language of the Sherman Act is all-inclusive, ${ }^{8}$ the leading case of Standard Oil Co. v. United States ${ }^{9}$ established the principle that only unreasonable restraints of trade are prohibited. This restrictive interpretation of the statute is now commonly referred to as the "rule of reason." Under this approach, the restraint must be evaluated in terms of its nature, purpose, and effects within the context of the specific commercial situation. ${ }^{10}$

The per se doctrine developed as an expedient substitute for the detailed inquiries involved in a rule of reason approach. Certain restraints by their very "nature" and "character" have been conclusively presumed to be unreasonable. ${ }^{11}$ The Court looks only to the act itself, concluding ipso facto that it cannot be justified and probably will be repeated in the future. Thus, even if only an insubstantial amount of trade is immediately restrained, the Court finds a "monopolistic tendency"12 within the prohibitions of the Sherman Act. ${ }^{13}$ Since unreason-

${ }^{7} I d$, at 200 .

'The Sherman Act prohibits every contract, combination, or conspiracy in restraint of trade.

22 I U.S. I (Igrr).

${ }^{20}$ Perhaps the most coinprehensive statement of the rule of reason approach is that made by the Supreme Court in Board of Trade v. United States: "[T] ordinarily consider the facts peculiar to the business to which the restaint is applied; its condition before and after the restraint was imposed; the nature of the restraint and its effect, actual or probable. The history of the restraint, the evil believed to exist, the reason for adopting the particular remedy, the purpose or end sought to be attained, are all relevant facts. This is not because a good intention will save an otherwise objectionable regulation or the reverse; but because knowledge of intent may help the court to interpret facts and to predict consequences." 246 U.S. 23 r, 238 (1918). For similar statements of the relevant inquiries, see Times-Picayune Publishing Co. v. United States, 345 U.S. 594, 615 (1953); United States v. Columbia Steel Co., 334 U.S. 495,527 (1948).

${ }^{11}$ See, e.g., Klor's, Inc. v. Broadway-Hale Stores, Inc., 359 U.S. 207 (1959) (group boycott); Northern Pacific Ry. v. United States, 356 U.S. I (r958) (tying arrangement); United States v. Socony-Vacuum Oil Co., 3 ro U.S. r5o (r940) (pricefixing).

${ }^{10}$ E.g., Klor's, Inc. v. Broadway-Hale Stores, Inc., supra note 11 ; at 213 ; International Salt Co. v. United States, 332 U.S. $392 ; 396$ (1947).

${ }^{13}$ In discussing the common law prohibitions against restraints of trade which the Sherman Act was held to include, the Court in Standard Oil Co. v. United States, 22 I 
ableness is presumed, the plaintiff need only establish the alleged operative acts plus injury to himself. ${ }^{14}$

Although the Supreme Court had often utilized the per se doctrine in situations involving concerted refusals to deal, ${ }^{15}$ lower courts ${ }^{10}$ and commentators $^{17}$ questioned the applicability of such a rule to all cases. ${ }^{18}$

U.S. I, 57 (1911), said that "contracts or acts which it was considered had a monopolistic tendency ... came also in a generic sense to be spoken of ... as restricting the due course of trade, and therefore as being in restraint of trade." Sec Times-Picayune Publishing Co. v. United States, 345 U.S. 594, 623 (1953) (monopolistic designs as well as results reached by the prohibitions of the Sherman Act). The underlying rationale was expressed by the Court in Swift \& Co. v. United States: "Where acts are not sufficient in themselves to produce a result which the law seeks to prevent . . . an intent to bring it to pass is necessary in order to produce a dangerous probability that it will happen. . . . But when that intent and the cousequent dangerous probability exist, this statute . . . directs itself against that dangerous probability as well as against the completed result." 196 U.S. 375,396 (1905).

${ }^{16}$ Thus, in the Radiant Burners case it would seem that proof of the agreement not to supply gas for use in burners not approved by AGA and resulting injury will entitle the plaintiff to recover. The defendants will not be allowed the defense that their refusal to sell was justified and based upon reasonable standards. Nor will the plaintiff be required to prove that his burner was safe or that the defendants' purpose was to control the market.

${ }^{16}$ See, e.g., Fashion Originators' Guild of America, Inc. v. FTC, 312 U.S. 457 (1941); Sugar Institute, Inc. v. United States, 297 U.S. 553 (1936); Binderup v. Pathe Exch., Inc., 263 U.S. 29 I (1923); Eastern States Retail Lumber Dealers' Ass'n v. United States, 234 U.S. 600 (1914). In none of these cases did the Court make it clear whether the unreasonableness was due to the surrounding circumstances or to the adoption of a boycott in and of itself. For instance, in the Fashion Originators' Guild case, although exclusion of evidence as to the reasonableness of the hoycott was upheld, the Court discussed at length the economic effects of the boycott on the market and thus may have felt that these effects were sufficiently unreasonable to preclude any justification.

In addition to the cases specifically dealing with group boycotts, dicta in others have categorized boycotts as illegal per se. Times-Picayune Publishing Co. v. United States, 345 U.S. 594, 625 (1953); United States v. Columbia Steel Co., 334 U.S. 495, $522(1948)$.

${ }^{10}$ See, e.g., Ruddy Brook Clothes, Inc. v. British \& Foreigu Marine Ins. Co., 195 F.2d 86 (7th Cir. 1952); Butterick Publishing Co. v. FTC, 85 F.2d 522 (2d Cir. 1936); United States v. New Orleans Ins. Exch., 148 F. Supp. 915 (E.D. La. 1957); United States v. Insurauce Bd. of Cleveland, 144 F. Supp. 684 (N.D. Ohio 1956).

${ }^{17}$ See, e.g., Handler, Annual Review of Recent Antitrust Developments, 12 RECORD of N.Y.C.B.A. 411 (1957); Barber, Refusals to Deal Under the Federal Antitrust Lasus, ro3 U. PA. L. REv. 847 (1955); Oppenheim, Federal Antitrust Legislationt: Guideposts to a Revised National Antitrust Policy, 50 MrCH. L. Rev. 1139 (1952).

${ }^{18}$ In earlicr cases the Supreme Court had applied a standard of reasonableness to some group refusals to deal. In Anderson v. United States, 171 U.S. 604 (1898), members of a cattle exchange had agreed not to deal with any non-member trader. The Court upheld this boycott because the amouut of trade affected was insubstautinl and the exchange's purpose was to. foster an organized market, thus promoting rather 
Then, in Klor's, Inc. v. Broadway-Hale Stores, Inc., ${ }^{19}$ the Court held that a complaint alleging a refusal by major manufacturers to sell their electrical appliances to an individual retailer established a per se violation and that the defendants' affidavits as to the reasonableness of the restraint were no defense. Rather than restrict its holding to those combinations whose singular purpose is to eliminate competition, the Court went further and stated in unqualified terms that group boycotts and combined refusals to deal are per se illegal. ${ }^{20}$

The instant case, dealing with activities of a trade association, afforded the Court an opportunity to delimit the scope of the Klor's rule for unlike the purpose of the combination in that case, AGA's objectives went beyond the mere elimination of competition, and some justification could be offered in defense of its activities. Nevertheless, rather than remand for application of a rule of reason test, ${ }^{21}$ the Court

than obstructing commerce. Appalachian Coals, Inc. v. United States, i 88 U.S. 344 (r933), dealt with the adoption by competing coal producers of a common selling agent. Since the coal industry was in distress and the plan had not yet been put into effect, the Court found no "monopolistic menace" and upheld the restraint as reasonable under the circumstances; it was suggested that new proceedings could be initiated if adverse effects upon competition should develop from actual operation of the program.

19359 U.S. 207 (1959).

${ }^{20} I d$. at 212 . Most commentators have expressed dissatisfaction with the allencompassing prohibition laid down by the Klor's case. See, e.g., Handler, Recent Developments in Antitrust Law: r958-r959, 59 Colum. L. Rev. 843 (1959); Rahl, Per Se Rucles and Boycotts Under the Sherman Act: Some Reflections on the Klor's Case, 45 VA. L. REv. Ir65 (1959). A recent district court case, United States v. Insurance Bd. of Cleveland, 188 F. Supp. 949 (N.D. Ohio r 960 ), held that in absence of coercive economic pressure, a group refusal to deal is to be tested under the rule of reason. This decision seems inconsistent with Klor's.

21 The Court of Appeal's requirement of "public injury," in the sense of appreciable lessening in the sale of gas burners or depriving the public of a product of over-all superiority, would seem to be inconsistent with Radovich v. National Football League, 352 U.S. 445 (1957). In that case the lower court had dismissed a complaint for failure to allege "public injury." The Supreme Court reversed, holding that a complaint in a treble damage suit "need only be 'tested under the Sherman Act's general prohibition on unreasonable restraints of trade' .... Congress has, by legislative fiat, determined that such prohibited activities are injurious to the public .... [T] his Court should not add requirements to burden the private litigant beyond what is specifically set forth by Congress ...." 352 U.S. at 453-54. On a motion to dismiss, the complaint should be liberally construed and all reasonable inferences of fact drawn in the plaintiff's favor. See IA Barron \& Holtzoff, Federat Practice and Procedure $\$ 255$ (rev. ed. 1960). Thus, it would be seem that the complaint in the instant case had sufficiently alleged facts from which a "monopolistic tendency" could be found. See note 14 stipra.

Even under the appellate court's narrow concept of "public injury," plaintiff's allegation that his burner was safer and more efficient than those previously approved 
chose instead to reaffirm the blanket prohibition laid down by Klor's, thereby discarding justification and good motive as possible limitations to the per se doctrine as applied to group refusals to deal. The Court has thus made it clear that even trade associations, regardless of their raison d'être and reasonable standards, may not effectuate their policies through refusals to deal. ${ }^{22}$

The Court's restrictive attitude toward trade association activities is based on valid policy considerations. Free market access is essential to an effective competitive order. ${ }^{23}$ Therefore, no group should be allowed to foreclose the market to any competitor. The public, not a private group, should make the ultimate decision as to whether a product is worthy to compete. Protection of the public from dangerous products and protection of business from trade abuses are governmental functions not to be entrusted to an unregulated private group. ${ }^{24}$

On the other hand, it cannot be expected that the Government will regulate all fields of economic activity in need of some form of control. Therefore, a restricted degree of cooperative trade activity should be

by the AGA should have satisfied, for purposes of withstanding a motion to dismiss, the requirement of alleging that the public had been deprived of a product of overall superiority.

${ }^{29}$ By placing its emphasis on the refusal to sell, the Court avoided the necessity of considering the legality of the defendants' refusal to grant plaintiff's burner a seal of approval. The confidence placed by the public in seals of approval, such as those given by the Consumers' Research Institute and the Good Housekeeping Institute, undoubtedly has some effect on the marketability of nonapproved products. Whether or not an unreasonable refusal to grant approval in and of itself will be subject to condemnation under the Sherman Act will have to be decided in future cases.

${ }^{23}$ See Report of the Attorney General's National Committee to Study THE ANTITRUST LAws 326 (1955): "From the economic point of view, relative frecdom of opportunity for entry of new rivals is a fundamental requisite for effective competition in the long run." See also International Salt Co. v. United States, 332 U.S. 392, 396 (1947); Associated Press v. United States, 326 U.S. 1, $13-14$ (1945); Barber, supra note 17.

${ }^{24}$ See Associated Press v. United States, 326 U.S. I (1945); Fashion Originators? Guild of America, Inc. v. FTC, 312 U.S. 457 (1941). In the Associated Press case the Court characterized the combination in question as an "extra-governmental agency, which prescribes rules for the regulation and restraint of interstate commerce, and provides extra-judicial tribunals for determination and punishment of violations, and thus 'trenches upon the power of the national legislature ... " 326 U.S. at 19. But compare the dictum of Chief Justice Hughes in Sugar Institute, Inc. v. United States, 297 U.S. 553, 598 (1936): "[The Sherman Act prohibitions] do not prevent the adoption of reasonable means to protect interstate commerce from destructive or injurious practices and to promote competition upon a sound basis. Voluntary action to end abuses and to foster fair competitive opportunities in the public interest may be more effective than legal processes." 
allowed and a competitor alleging injury as a result of such activities should be required to prove that the particular conduct complained of was "unreasonable." Thus, a rule of reason standard applied to the Sherman Act, complemented by state tort remedies, ${ }^{25}$ should provide adequate protection against any abuse of the association's regulatory powers.

Perhaps the greatest danger of applying a per se rule to trade associations is that fear of treble damage actions may discourage many economically and socially desirable group self-betterment activities. Often, associations' rules, by improving trade standards, will benefit both the trade and the public. In the instant case the defendants were prepared to justify their activities on the ground that public reaction to appliance failures reduced the market for gas appliances and consequently for gas itself. Self-imposed restrictions as to manufacturing standards thus could provide the public with more dependable appliances and, by encouraging public acceptance of gas appliances, benefit all segments of the gas industry. ${ }^{26}$ These positive functions of trade associations should not be overlooked when evaluating the wisdom of applying a rule of per se illegality. ${ }^{27}$

In addition, since many trade associations have no monopolistic intent, it will not be true that all of their refusals to deal will have the "monopolistic tendency" which a per se holding presumes. Given reasonable standards and a purpose consistent with maintainance of competition, an association's refusal to deal may cause no harm, actual or potential, to the competitive process. Yet the per se rule, focusing solely upon the act itself, disregards standards, intent, and demonstrable consequences and thus presumes an effect on competition not present in all cases. Since the per se presumption is not consistent with the actual social and economic consequences of many trade associations' refusals to deal, a finding of unreasonableness should be made only after the deeper inquiry afforded under the rule of reason.

${ }^{25}$ For possible tort remedies, see Restatement, TorTs $\$ \$$ 765-772 (1939), Concerted refusals to deal are actionable torts unless justified. The factors considered on the issue of justification are essentially those considered under a rule of reason approach to the Sherman Act. See Restatemant, TORTs $\$ 7_{6}(2)$ (1939).

${ }^{20}$ Brief for Respondents, pp. 24-25.

${ }^{27}$ See Oppenheim, supra note 17 , at $1 \times 7 \times-75$. After discussing the need for cooperative endeavors among competitors, Oppenheim suggests that "the underlying problem of delimiting the appropriate 'functional area of cooperative action' in harmony with the objectives of the federal anti-trust laws present issues of public policy on which the guiding yardstick of the Rule of Reason offers the best prospects of solution." Oppenheim, supra note 17 , at 1172 . 